\title{
SHELL VARIABILITY IN TROPHON GEVERSIANUS (GASTROPODA: MURICIDAE) AT CALETA DE LOS LOROS (NORTHERN PATAGONIA, ARGENTINA) DURING THE LATE HOLOCENE: A STRONG LOCAL IMPRINT
}

\author{
MARIANO E. MALVÉ1, GISELA A. MORÁN ${ }^{2,3}$, AND SANDRA GORDILLO2,3 \\ 'Facultad de Ciencias Naturales y Ciencias de la Salud, Universidad Nacional de la Patagonia San Juan Bosco, Ruta Provincial 1 s/n, 9000, Comodoro Rivadavia, Argentina. \\ 2Facultad de Ciencias Exactas, Físicas y Naturales, Universidad Nacional de Córdoba, Av. Vélez Sarsfield 299, X5000JJC, Córdoba, Argentina. gisela.amoran@gmail.com; \\ sandra.gordillo@unc.edu.ar \\ ${ }^{3}$ Centro de investigaciones en Ciencias de la Tierra (CICTERRA), Consejo Nacional de Investigaciones Científicas y Tecnológicas (CONICET), Av. Vélez Sarsfield 1611, \\ X5016GCA, Córdoba, Argentina.
}

G.A.M. present address: Instituto de Diversidad y Ecología Animal (IDEA, CONICET-UNC). Av. Vélez Sársfield 299 (X5022QXF) Córdoba, Argentina.

S.G. present address: Instituto de Antropología de Córdoba, IDACOR, CONICET, Universidad Nacional de Córdoba, Córdoba, Argentina. Universidad Nacional de Córdoba, Facultad de Filosofía y Humanidades, Museo de Antropología, Córdoba, Argentina. Av. Hipólito Yrigoyen 174, X5000 Córdoba, Argentina.

\begin{abstract}
Environmental change, such as variation in upwelling and the consequent fluctuation in marine primary productivity, may have profound effects on organisms. Trophon geversianus shells from Caleta de Los Loros (San Matías Gulf, Northern Patagonia, Argentina) were analyzed in order to compare morphological variability at different spatio-temporal scales. To do so, we performed morphometric analyses at three sites, two fossil deposits of different age from the late Holocene and one modern assemblage. In general, modern shells were thicker than fossil ones. A slight trend of size reduction is also observed over the time considered, since modern shells were, on average, smaller than fossil ones. Size variations of $T$. geversianus shells are explained on the basis of phenotypic plasticity as a response to the environmental changes recorded in the San Matías Gulf during the Holocene. These changes include variations in paleo-productivity, such as sea surface temperatures, salinities and water circulation changes, which would have modified nutrient availability. Furthermore, Caleta de Los Loros was validated as an outlier site along a latitudinal gradient. Shells from this peculiar place bear a closer resemblance to shells found in sites further south in the Magellan Province. Environmental conditions and oceanographic features related to the presence of upwelling events that were probably responsible for this pattern are discussed.
\end{abstract}

Key words. Death assemblages. Upwelling events. Latitudinal gradient. Outlier site. Morphometric analyses. Gastropod.

Resumen. VARIABILIDAD DE LA CONCHILLA EN TROPHON GEVERSIANUS (GASTROPODA: MURICIDAE) EN CALETA DE LOS LOROS (PATAGONIA NORTE, ARGENTINA) A LO LARGO DEL HOLOCENO TARDÍO: UNA FUERTE IMPRONTA LOCAL. Los cambios ambientales como la variación en los eventos de surgencia y la consiguiente fluctuación en la productividad primaria marina pueden tener profundos efectos en los organismos. En el presente trabajo, se analizaron conchillas de Trophon geversianus provenientes de Caleta de Los Loros (Golfo San Matías), con el fin de comparar la variabilidad morfológica a distintas escalas espacio-temporales. Para ello se realizaron análisis morfométricos en tres sitios, dos depósitos fósiles del Holoceno tardío y un ensamble moderno. En general, las conchillas modernas fueron más gruesas que las fósiles, observándose una ligera tendencia a la reducción de tamaño a través del tiempo considerado ya que las conchillas modernas fueron, en promedio, más pequeñas que las fósiles. La variación del tamaño de las conchillas de $T$. geversianus se explica sobre la base de la plasticidad fenotípica de la especie como respuesta a los cambios ambientales registrados en el Golfo San Matías durante el Holoceno. Estos cambios incluyen variaciones en la paleoproductividad, como la temperatura de la superficie del mar, salinidad y cambios en la circulación del agua, que habrían modificado la disponibilidad de nutrientes. Además, se validó Caleta de Los Loros como un sitio atípico a lo largo de un gradiente latitudinal. Las conchillas de Caleta de Los Loros se parecen más a aquellas encontradas en sitios más al sur en la Provincia Magallánica. Finalmente, se discuten las características ambientales y oceanográficas relacionadas con la presencia de eventos de surgencia que probablemente son los principales responsables del patrón observado.

Palabras clave. Ensambles de valvas. Eventos de surgencia. Gradiente latitudinal. Sitio atípico. Análisis morfométricos. Gasterópodo. 
MARINE GASTROPODS are among the groups most frequently studied for interpreting drivers of morphological variation (e.g., Ramajo et al., 2013; Cazenave \& Zanatta, 2016). For instance, shell shape variability has been evaluated in association with environmental gradients (Caley et al., 1995; Trussell, 2000; Trussell \& Smith, 2000; Ramajo et al., 2013), thermal stress and wave forces (Trussell et al., 1993; Denny, 2006; Harley et al., 2009), tenacity, and shell thickness (Vermeij \& Covich, 1978; Trussell et al., 1993), and even with paleoenvironmental changes (Gentry et al., 2008). Environmental change, such as variations in upwelling intensity and the consequent variation in marine primary productivity, may have profound effects on the morphology of calcareous organisms (Teusch et al., 2002); nevertheless, studies addressing this line of research are limited.

In a recent study, Malvé et al. (2018b) evaluated biogeographic shell shape variation in the marine snail Trophon geversianus, and recognized two morphotypes matching the biogeographic scheme of the Argentine Sea. In a previous study on the same species, Malvé et al. (2018a) also found that neither shell length nor relative shell weight showed any monotonic latitudinal trend, and the patterns of spatial variability were rather complex. These authors recognized a weak, non-significant, tendency of body size increase towards the south, with extremely large individuals at the Magellan Strait and Beagle Channel (southern South America). Surprisingly, larger sizes were later observed towards the northern end of the species' geographic distribution at Caleta de Los Loros (Northern Patagonia), not in accordance with the smaller sizes of the neighboring localities. This situation led to the need to consider this site in further detail.

In this respect, if a few sites along latitudinal gradients are found to deviate way beyond the expected general trend, they are identified as outliers and must be interpreted bearing in mind both the biological and physical factors (Nekola, 2010). This context reinforces the idea that local and regional scales are interrelated (Huston, 1999; Resetarits, 2005), and thus studying outlier sites may give us important insights into the local features of an area that can override the large-scale processes that drive regional grouping patterns (Blanchette et al., 2008). Moreover, throughout the geographic range of a species, the distinctiveness and peculiarity of particular sites may disrupt expected general patterns (e.g., ecogeographic rules) when considering multi- ple sites at a regional scale (Malvé et al., 2018a). Embracing a regional approach is therefore of paramount importance since studies that cover the entire geographic range of a species along the south-west Patagonian coast (from Río Negro Province to Tierra del Fuego) are scant, thus limiting our ability to answer basic biogeographic questions (Fenberg \& Rivadeneira, 2011).

Trophon geversianus is a common and widespread inhabitant of intertidal and shallow subtidal environments. On the south-west Atlantic coast, this species is reported from $35^{\circ} \mathrm{S}$ to $56^{\circ} \mathrm{S}$ (including the Malvinas Islands), while on the south-east Pacific coast it ranges from $42^{\circ} \mathrm{S}$ to $56^{\circ} \mathrm{S}$ (Griffin \& Pastorino, 2005; Pastorino, 2005). This marine snail is dioecious, with internal fertilization and intra-capsular embryonic development (Zaixso, 1973; Penchaszadeh, 1976). For this genus, planktonic larvae are not known (Pastorino, 2005), there is no evidence of external sexual dimorphism, and the sex ratio is different from 1:1, with a bias towards females (Cumplido et al., 2010). The shell size (up to $100 \mathrm{~mm}$ ) is extremely variable, as can be appreciated from the large number of names proposed for the different morphological variants of this species (Pastorino, 2005). To excavate a drill-hole, this drilling gastropod penetrates the shell of their prey by a mechanical scraping action of the radula, together with chemical activities of carbonic anhydrase, chelating agents, and enzymes secreted by the ABO (accessory boring organ) situated in the foot (Carriker 1981).

On a local scale (three sites from Nuevo Gulf, Northern Patagonia), Márquez et al. (2015) revealed morphological variability in Trophon geversianus between intertidal and subtidal habitats probably attributed to phenotypic plasticity, since phylogenetic analysis of col gene fragments showed no consistent differences among individuals sampled in both habitats. These authors found two ecomorphs of $T$. geversianus as a response to physically stressful conditions on intertidal rocky shores (as opposed to lower physical stress but higher predation pressure in subtidal habitats). This finding corroborates those of Pastorino (2005) with respect to the extremely variable nature of $T$. geversianus shells, not only from North to South but also from intertidal to subtidal environments. At least in part, this variability is attributed to the high environmental heterogeneity of the southwestern Atlantic coast of Patagonia (Yorio et al., 2015), the product of an intricate coastal to- 
pography, which enables the establishment of local communities. High environmental heterogeneity, coupled with the presence of ecosystem engineer species such as matrices of scorched mussels (Brachidontes rodriguezii and Perumytilus purpuratus) (Prado \& Castilla, 2006; Borthagaray \& Carranza, 2007; Sueiro et al., 2010) where T. geversianus partly inhabits, may be responsible for the great variability of intertidal communities over small spatial scales (sometimes in the order of meters) within the same area (Kelaher et al., 2007).

This study focuses on fossil and modern shells collected at Caleta de Los Loros (San Matías Gulf) in order to further understand morphological variations of Trophon geversianus on a local scale, taking into account the peculiarity of this site in relation to a latitudinal gradient of 14 degrees along the southwestern Atlantic coast. This locality in Northern Patagonia is proposed and confirmed here for the first time as an outlier site. The specific goals were: i) to compare size variation between late Holocene and modern shells from Caleta de los Loros; ii) to compare size variation between Holocene and modern shells in the northern and southern Atlantic geographic distribution of the species; and iii) to validate Caleta de Los Loros as an outlier site along the Atlantic coast of Patagonia.

\section{GEOLOGICAL SETTING}

Caleta de Los Loros (located between $41^{\circ} 01^{\prime} 25^{\prime \prime} \mathrm{S}$ and $64^{\circ} 06^{\prime} 20^{\prime \prime} \mathrm{W}$ ) is a Patagonian natural protected area with a wide variety of geographical features and environments such as dunes, rocky and sandy shores, cliffs, salt marshes, and beach ridges. Within these units there are three fossil spits of Holocene age indicating a growth pattern from east to west (Del Río \& Colado, 1999; Sander et al., 2018). Using optically stimulated luminescence (OSL) chronology, Sander et al. (2018) established surprisingly young ages in the Holocene evolution of Caleta de Los Loros. According to these studies, sedimentary successions in the distal part of the system formed prior to c. 2300 years BP, while the larger and more exposed western part of the system and the lagoon formed over the last c. 1000 years BP. Therefore, the oldest preserved lagoonal deposits formed in the protected inner part of the system, as is the case of $\mathrm{H} 2$ (see Fig. 1) and a younger deposit between c. 1000 and 500 years formed in the more exposed western part of the system as is the case of $\mathrm{H} 1$ (see Figure 1) (Sander et al., 2018).

Caleta de Los Loros is a cove located in the San Matías Gulf, Argentina's second largest gulf, in Río Negro province (Fig. 1), with an area of approximately $18,000 \mathrm{~km}^{2}$. Being a semienclosed basin, the distribution of the physical properties and its evolution are basically governed by the interchange with the atmosphere and with the open ocean through the mouth of the gulf (Gagliardini \& Rivas, 2004). Although the exchange with the open sea affects the physical conditions found inside the gulf, its particular geometry (shallow, with a pronounced sill that limits its mouth) means that the atmospheric forcing is of greatest importance (Rivas, 1990).

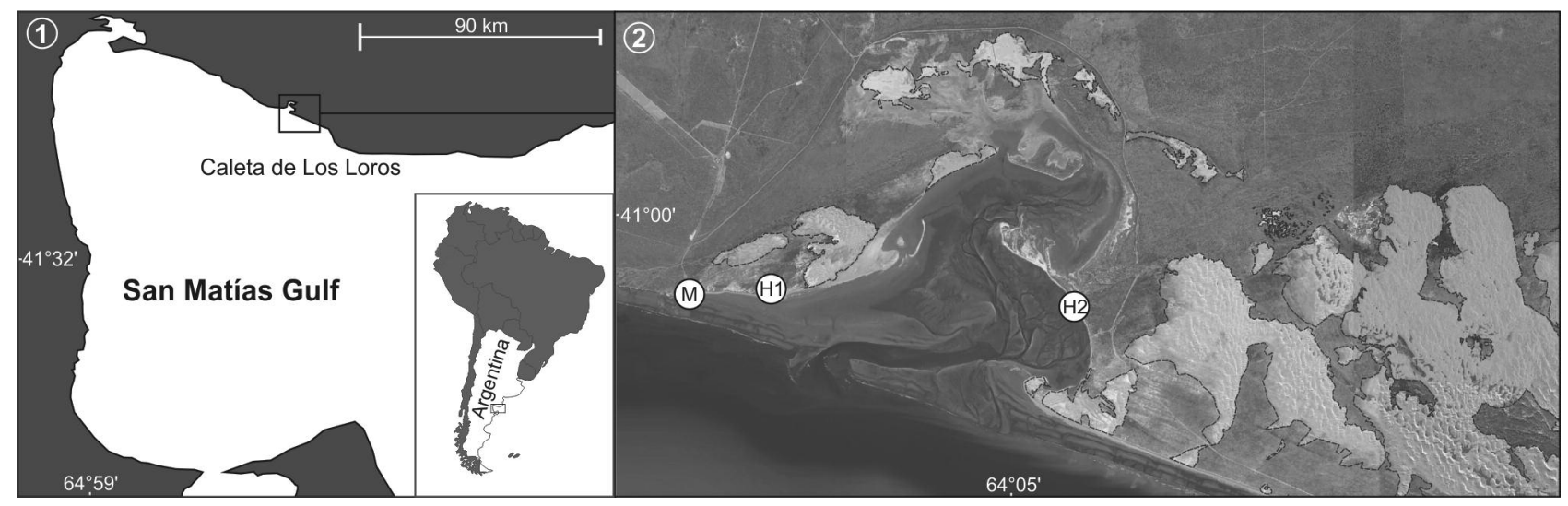

Figure 1. Study area and sampling sites. 1, Regional map showing the location of Caleta de Los Loros inside the San Matías Gulf. 2, Detailed map showing the three deposits analyzed: (M) A modern site from an active beach, (H1) a Holocene site in the more exposed western part of the system, and $(\mathrm{H} 2)$ another Holocene site in the oldest preserved lagoonal deposits. $\mathrm{H} 1$ is younger than $\mathrm{H} 2$. See details in text. Satellital imagery credits: Data SIO, NOAA, U.S. Navy, NGA, GEBCO; Image ๑ 2017 Maxar Technologies; 2017 @ Google; Image ๑ 2017 TerraMetrics. 
Additionally, cyclonic gyres have been documented near Caleta de Los Loros (Piola \& Scasso, 1988), and these have important consequences for marine ecosystems. Cyclonic gyres result in the rise of deep waters (upwelling), involving the wind-driven motion of dense, cooler, and usually nutrient-rich water towards the surface, replacing the warmer, usually nutrient-depleted surface water. This increased availability of high concentrations of chlorophyll- $a$ in upwelling regions results in high levels of primary productivity, thereby favoring fishery production in the zone where the cyclonic gyre occurred.

\section{MATERIALS AND METHODS}

Sampling and data sets. For the morphometric analyses of Caleta de Los Loros (see below), 198 empty Trophon geversianus shells were selectively collected from three sites, one modern ( $\mathrm{N}=70)$ and two fossil $(\mathrm{H} 1, \mathrm{~N}=73$ and $\mathrm{H} 2$, $\mathrm{N}=55$ ) assemblages in December 2016.

Paleontological material from Holocene marine terraces in the Beagle Channel (southern geographic distribution of the species) was obtained using volumetric samples which consisted of $10 \mathrm{dm}^{3}$ bulk sediment; samples were sieved in the field using $1 \mathrm{~mm}$ and $0.05 \mathrm{~mm}$ sieves to reduce the volume. These terraces correspond to Río Ovando site $\left(54.50^{\circ} \mathrm{S}, 68.35^{\circ} \mathrm{W}\right)$ and are determined by ${ }^{14} \mathrm{C}$ at $3839 \mathrm{yr}$ BP (Gordillo et al., 2015). The associated fauna of this assemblage includes macromollusks such as clams Tawera gayi, Ameghinomya antiqua, and the bivalve Hiatella solida. Among gastropods, the most common taxa are the muricid Xymenopsis muriciformis and one buccinid Pareuthria plumbea. These fossil shells from the Beagle Channel (southern tip of South America, $54.83^{\circ} \mathrm{S}$ ) were compared with fossil shells from Caleta de Los Loros (northern Patagonia, 41.05 $\mathrm{S}$ ).

To validate Caleta de Los Loros as an outlier site, we used a data set (Tab. 1) compiled by Malvé et al. (2018b), of 849 modern shells from 14 other sites throughout Argentinean Patagonia, which encompasses 14 degrees of latitude and covers most of the geographic range reported for $T$. geversianus along the southwestern Atlantic coast. Representative quadrat samples were used for modern shells. The molluscan death assemblage at each beach was sampled from the high-water mark every $10 \mathrm{~m}$, using 0.5

TABLE 1 - Detail of the 14 study sites $(\mathrm{N}=849$ ). A indicates Argentinean province and $\mathrm{M}$ corresponds to the Magellan province. The asterisk indicates the Transition Zone $\left(41^{\circ} \mathrm{S}-43^{\circ} \mathrm{S}\right)$ between the Argentinean and Magellan biogeographic provinces.

\begin{tabular}{|c|c|c|c|c|c|c|}
\hline Site & Latitude ( $\left.{ }^{\circ} \mathrm{S}\right)$ & Longitude $\left({ }^{\circ} \mathrm{W}\right)$ & $\begin{array}{l}\text { Biogeographic } \\
\text { province }\end{array}$ & Sample size & $\begin{array}{l}\text { Mean shell } \\
\text { length }(\mathrm{mm})\end{array}$ & $\mathrm{SD}(\mathrm{mm})$ \\
\hline Caleta de Los Loros (CL) & -41.05 & -63.58 & A & 100 & 44.42 & 8.71 \\
\hline Playas Doradas (PD) & -41.63 & -65.02 & $A^{*}$ & 25 & 21.68 & 7.04 \\
\hline Puerto Lobos (PL) & -41.99 & -65.07 & $A^{*}$ & 325 & 22.51 & 5.05 \\
\hline Puerto Pirámides (PP) & -42.35 & -64.17 & $A^{*}$ & 39 & 19.60 & 4.25 \\
\hline Puerto Madryn (PM) & -42.78 & -65.04 & $A^{*}$ & 59 & 18.14 & 6.11 \\
\hline Playa Elola (PE) & -44.84 & -65.73 & M & 26 & 31.59 & 10.45 \\
\hline Bahía Bustamante (BB) & -45.13 & -66.54 & M & 22 & 33.18 & 5.70 \\
\hline Rada Tilly (RT) & -45.94 & -67.56 & M & 28 & 31.59 & 8.88 \\
\hline Caleta Olivia (CO) & -46.49 & -67.48 & M & 37 & 36.51 & 6.58 \\
\hline Makenke (M) & -49.33 & -67.37 & M & 76 & 20.8 & 6.05 \\
\hline Punta Loyola (L) & -51.37 & -69.01 & M & 23 & 22.23 & 3.28 \\
\hline Strait of Magellan (MAG) & -52.40 & -69.49 & M & 22 & 47.29 & 20.35 \\
\hline Cabo Auricosta (A) & -54.05 & -67.31 & M & 38 & 32.17 & 7.23 \\
\hline Bahía Golondrina (BG) & -54.50 & -68.21 & M & 29 & 49.31 & 8.71 \\
\hline
\end{tabular}


x $0.5 \mathrm{~m}$ quadrats. Death assemblages typically include specimens spanning from a few years to hundreds of years (i.e., they are time-averaged, Kidwell, 2002, 2013; Archuby et al., 2015), which allows us to include multiple cohorts. In addition, death assemblages are also spatially averaged, and include shells from different types of habitat. Altogether, the use of time averaged death assemblages can increase the robustness of the analyses despite the short-term volatility of living assemblages. Taphonomic processes such as fragmentation, dissolution, abrasion and bioerosion can affect shell traits (Aguirre \& Farinati, 1999; Zuschin et al., 2003). However, most of the shells collected retain their characteristic ornamentation, thus suggesting that abrasion, dissolution, and bioerosion were negligible. Other taphonomic attributes were taken into account and minimized whenever possible, as was the case with fragmentation, since only whole (undamaged) shells were used in the analyses.

All studied specimens are stored in the mollusk collection of the repository at the Centro de Investigaciones en Ciencias de la Tierra (CICTERRA, CONICET-UNC), Córdoba, Argentina. Also, specimens illustrated are stored under numbers Cátedra de Estratigrafía y Geología Histórica (CEGH-UNC) 27423, 27424, and 27425.

Morphometric measurements. Seven morphometric characteristics were selected taking into account different reference studies (Chiu et al., 2002; Pizá \& Cazzaniga, 2003; Madec \& Bellido, 2007). Following the methodology used in Malvé et al. (2018b), all measurements were taken (Fig. 2). Shell length (SL) was measured along an axis passing through the apex to the bottom of the siphonal canal. Shell width (SW) is the maximum width perpendicular to the shell length measurement. Aperture length ( $A L$ ) is the length from the beginning of the suture to the bottom of the aperture. Aperture width (AW) is the maximum width of the aperture. Spire height (SH) was measured from the beginning of the suture to the apex of the shell. Shell thickness (ST) was measured in the middle of the aperture between inner and outer layers with a caliper. All characteristics were measured to the nearest millimeter with a digital caliper. The total weight of each shell (without soft tissues) was also measured, using a digital scale (TW) $(0.01 \mathrm{~g}$ of precision). See Supplementary Online Information for details on the morphometric data set.
Data analyses. For the morphometric analyses of Caleta de Los Loros, we compared the size variation of shells in three deposits: one modern ( $n=70$, active beach), and two fossil deposits at different shore levels, $\mathrm{H} 1$ (Holocene $1 ; 41^{\circ}$ 0' 51.33" S, $64^{\circ} 8^{\prime} 36.85^{\prime \prime} \mathrm{W} ; \mathrm{n}=73 ; 5 \mathrm{~m}$ a.s.l) and $\mathrm{H} 2$

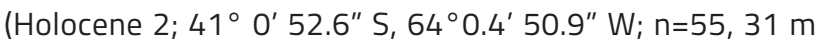
a.s.I). The different shore level between $\mathrm{H} 1$ and $\mathrm{H} 2$ may be interpreted as a proxy of age, thus the fossil assemblages are probably of different ages (see Sander et al., 2018), with $\mathrm{H} 1$ being a younger deposit than $\mathrm{H} 2$.

Given that $T$. geversianus exhibits allometric growth (Ostachuk, 2016), we applied Thorpe's size normalization (Thorpe, 1975). This technique eliminates the effects of body size from any trait, independently of its relation to body size, according to the following expression (Lleonart et al., 2000):

$$
Y^{*}=Y_{i}\left(X_{0} / X_{i}\right)^{b}
$$

Where $Y^{*}$ is the normalized trait, $Y_{i}$ is the original trait, $X_{i}$ is the individual body size, $X_{O}$ is the mean body size, and $\mathrm{b}$ is

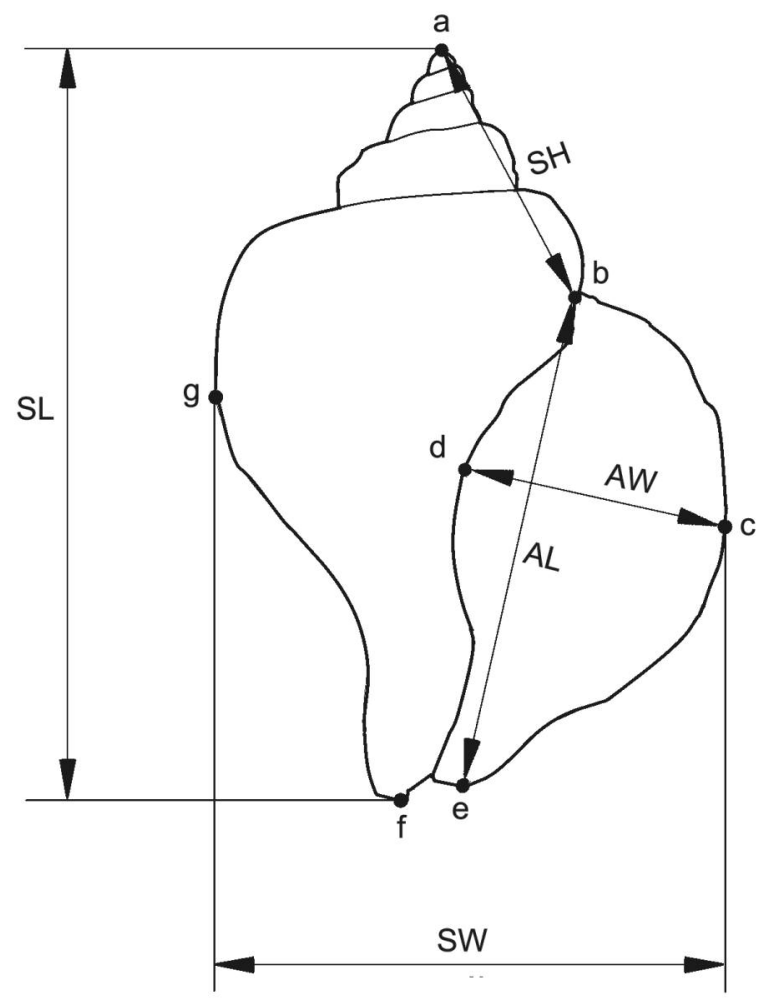

Figure 2. Shell measurements. Shell length (SL), shell width (SW), aperture length (AL, b-e), aperture width (AW, d-c), spire height (SH, $\mathrm{a}-\mathrm{b})$, and shell thickness (c). See details in text. 
the slope of the ordinary least squares regression between $Y_{i}$ and $X_{i}$ (after log-transformation). To visualize differences in each measurement between sites, a one-way ANOVA followed by the Tukey test was carried out for each measurement.

To validate Caleta de Los Loros as an outlier site, we used box-plots to analyze different shell traits such as length, thickness and relative weight (RW, cubic root of shell weight/shell length) along a latitudinal gradient. A cluster analysis using the Bray-Curtis coefficient was also performed to visualize groups among the 14 localities. Only modern shells and sites with $n>20$ were used.

\section{RESULTS}

Size variation between late Holocene and modern specimens. ANOVA and the a posteriori Tukey test showed significant differences in only two of the seven variables considered: shell thickness (ST) (between $\mathrm{H} 1$ and the mod-
(1)

55
50
55
40
45
30
30
SL

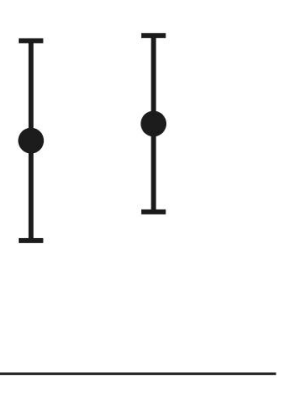

(2)

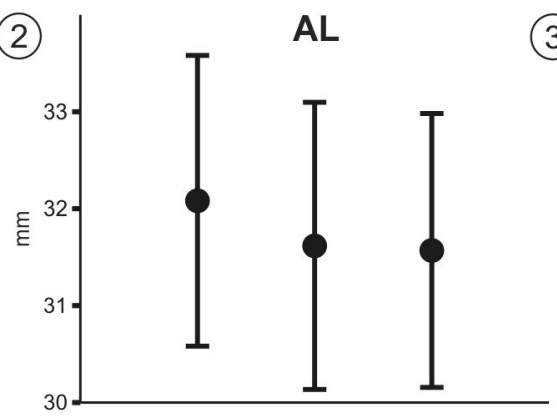

(3)

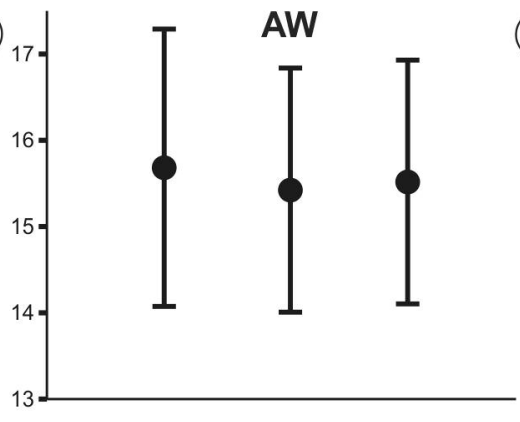

(4)

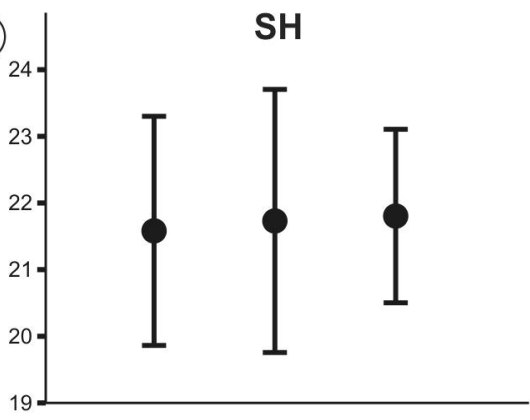

(5)

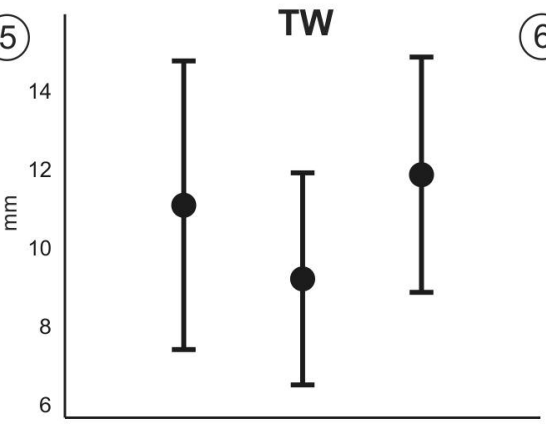

M

H1

H2
(6)

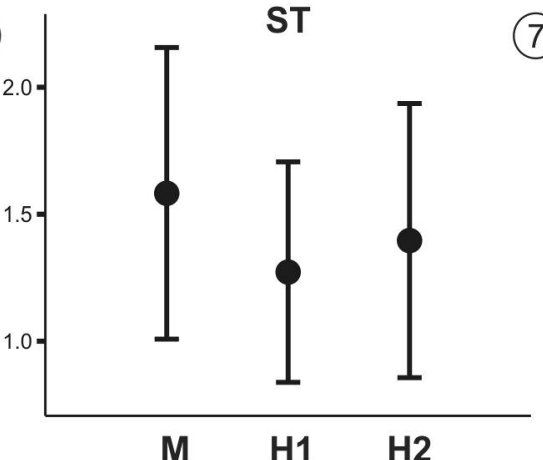

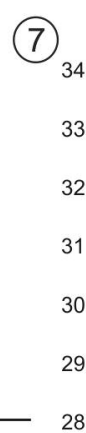

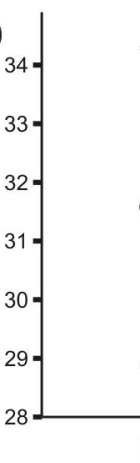

\section{SW}

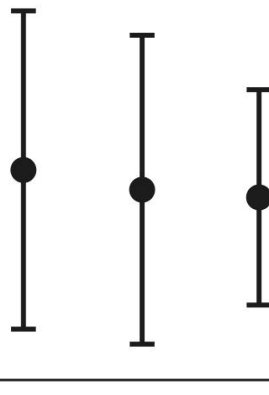

$\begin{array}{lll}M & \mathrm{H} 1 \quad \mathrm{H} 2\end{array}$

Figure 3. Differences between each measurement for each site (San Matías Gulf) showing mean and standard deviation after Thorpe's normalization. 1, SL= Shell length; 2, AL= Aperture length; 3, AW= Aperture width; 4, SH= Spire height; 5, TW=Total weight; 6, ST= Shell thickness; 7, SW= Shell width. Only TW and ST showed significant differences between sites. See details in text. 


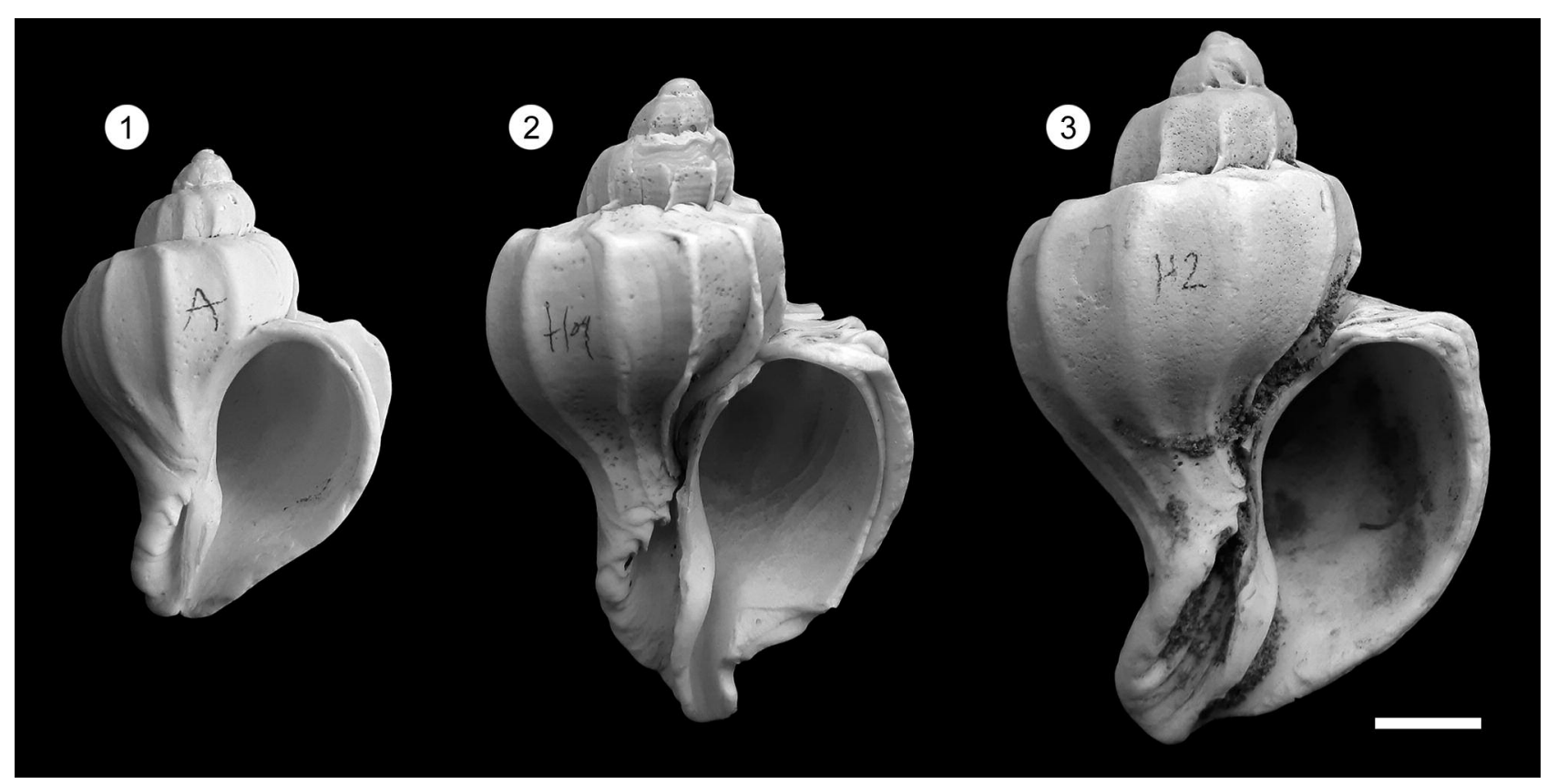

Figure 4. Illustrative representation of specimens from Caleta de Los Loros. 1, modern shell from an active beach; 2, Holocene shell from $\mathrm{H} 1$ (younger deposit); 3 , Holocene shell from H2 (older deposit). Specimens illustrated are stored under the following numbers: Cátedra de Estratigrafía y Geología Histórica (CEGH-UNC) 27423, 27424, and 27425. Scale bar equals $1 \mathrm{~cm}$.

ern assemblage, $F=6.22 ; \mathrm{p}<0.002$ ), and total weight (TW) (between the modern assemblage and $\mathrm{H} 1$, and between $\mathrm{H} 1$ and $\mathrm{H} 2, F=12.38, \mathrm{p}<0.001$ ) (Fig. 3). In general, $\mathrm{H} 1$ shells were thinner and lighter than the rest (Fig. 3). A slight nonsignificant trend of size reduction was also observed over the time considered, since modern shells were, on average, smaller than fossil ones (Figs. 3, 4).
Size variation between Holocene and modern shells at the northern and southern distribution of the species was opposite (Tab. 2). At the Beagle Channel (Magellan Province), modern shells were larger than fossil ones (ttest, $\mathrm{p}<0.0001)$, while no differences in size were found at Caleta de Los Loros (Argentinean Province) (t-test, p>0.05). Nevertheless, modern shells at Caleta de Los Loros were,

TABLE 2 - Comparison of shell traits between modern and fossil assemblages in Northern Patagonia (Caleta de Los Loros) and the southern tip of South America (Beagle Channel). * denotes correction after Thorpe's normalization. Trait size (mean \pm SD). Range size (minimum-maximum).

\begin{tabular}{|c|c|c|c|c|c|}
\hline & \multicolumn{3}{|c|}{ Caleta de Los Loros (Argentinean province) } & \multicolumn{2}{|c|}{ Beagle Channel (Magellan province) } \\
\hline & Modern & $\mathrm{H} 1$ & $\mathrm{H} 2$ & Modern & Fossil \\
\hline $\mathrm{SL}(\mathrm{mm})$ & $45.46 \pm 9.11$ & $47.41 \pm 7.49$ & $48.64 \pm 6.57$ & $49.31 \pm 8.71$ & $33.14 \pm 13.62$ \\
\hline range & $(17.17-65.73)$ & (34.21-63.30) & $(35.68-62.31)$ & $(34.60-73.70)$ & $(13.70-72.81)$ \\
\hline $\mathrm{ST} *(\mathrm{~mm})$ & $1.55 \pm 0.50$ & $1.27 \pm 0.43$ & $1.40 \pm 0.54$ & $1.66 \pm 0.42$ & $1.25 \pm 0.47$ \\
\hline range & $(0.69-2.54)$ & $(0.57-2.55)$ & $(0.57-2.60)$ & $(1.03-2.64)$ & $(0.44-2.20)$ \\
\hline$T W *(g)$ & $10.65 \pm 3.32$ & $9.21 \pm 2.70$ & $11.87 \pm 3.00$ & $6.05 \pm 1.13$ & $6.29 \pm 1.74$ \\
\hline range & (3.79-19.98) & (5.01-20.08) & $(5.59-18.34)$ & $(3.45-8.40)$ & $(3.39-9.36)$ \\
\hline N & 70 & 73 & 55 & 29 & 30 \\
\hline
\end{tabular}


(1)

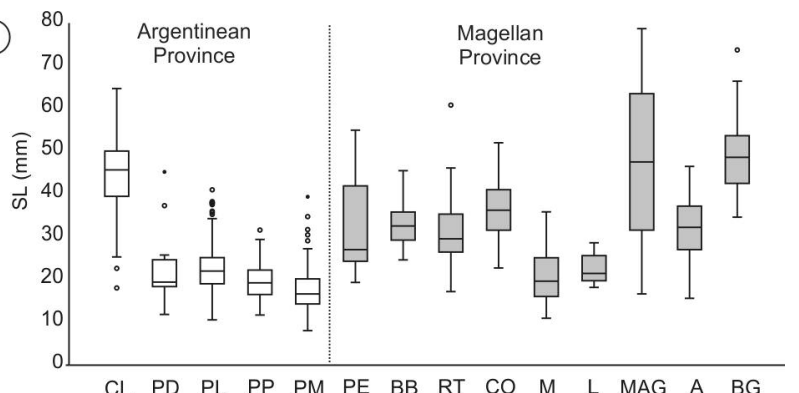

(2)

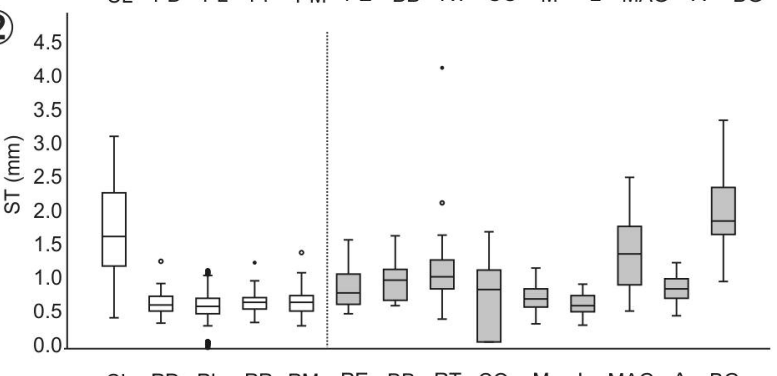

CL PD PL PP PM PE BB RT CO M L MAG A BG

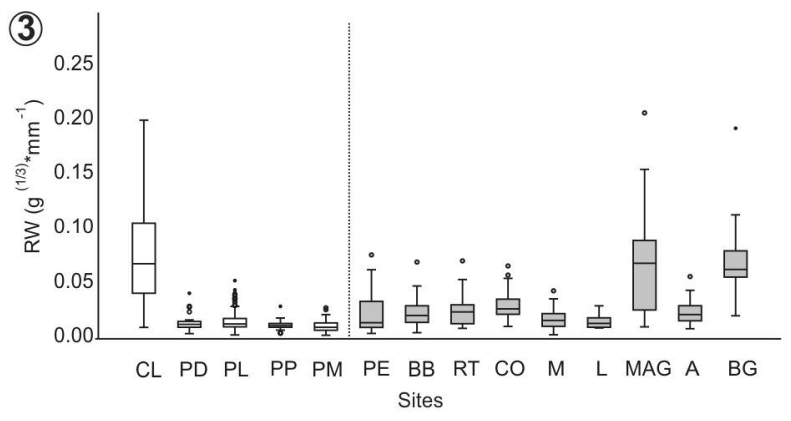

Figure 5. Boxplots showing the relationship between: 1, shell length and latitude; $\mathbf{2}$, shell thickness and latitude; $\mathbf{3}$, shell relative weight (RW) and latitude. Point line represents the boundary of the biogeographic provinces. Sites from North (left) to South (right), see references in Table 1. Only modern shells were used.

on average, smaller than fossil ones (see tendency of shell length in Figs. 3, 4 and Tab. 2). Range size in modern shells at Caleta de Los Loros was considerably wider compared to $\mathrm{H} 1$ and $\mathrm{H} 2$ (Tab. 2), while the reverse was observed between range sizes in modern and fossil assemblages at the Beagle Channel. On the other hand, modern shells were thicker than fossil ones irrespective of geographic location (t-test, $\mathrm{p}<0.001$ for all cases) (Tab. 2).

Caleta de Los Loros as an outlier site. Shell length, shell thickness, and relative weight validate Caleta de Los Loros as an outlier site in comparison with sites nearby from the Argentinean biogeographic Province (Fig. 5). Cluster analysis showed the presence of two major groups that separates fairly well sites according to the biogeographic provinces

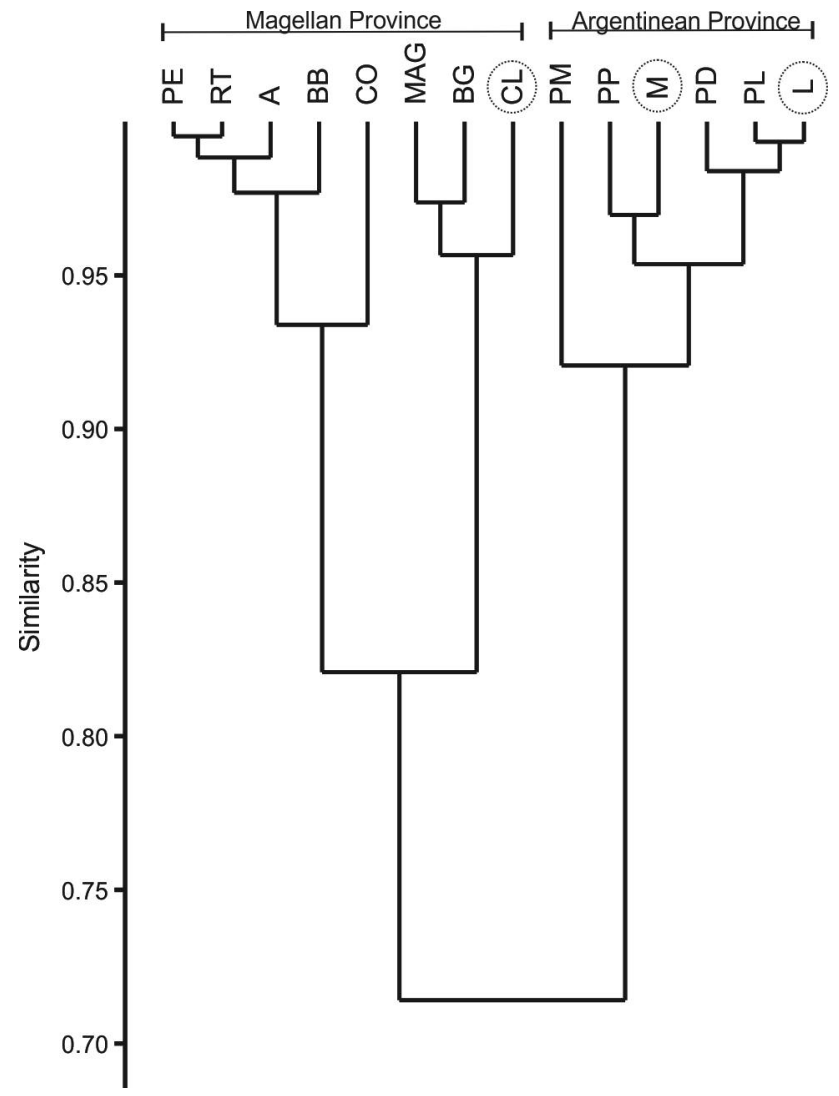

Figure 6. Cluster using Bray-Curtis coefficient based on shell traits: shell length, shell thickness and relative weight. See references in Table 1. Three sites are circled, Caleta de Los Loros that grouped with sites from the Magellan Province, and two sites from the Magellan Province that grouped with the Argentinean Province (see explanation in text).

(Fig. 6). Caleta de Los Loros is part of a well-defined group with sites located more than $1000 \mathrm{~km}$ southwards, such as the Strait of Magellan and Bahía Golondrina (Beagle Channel) at the southern tip of South America (Fig. 6). However, two localities from the Magellan Province (Makenke and Punta Loyola) showed shells with smaller sizes that grouped together with sites from the Argentinean Province.

\section{DISCUSSION}

Size variation between fossil and modern shells. Our results show a slight, non-significant trend of a decrease in size in modern samples compared with fossils at Caleta de Los Loros, contrary to previous reports (size increase over recent geological time) for the same species from the Beagle Channel (southern tip of South America) (Malvé et al., 2018b). New samples taken along the study area would be 
necessary to better elucidate this situation. However, why does this species show a different tendency of body size throughout the late Holocene along its geographic distribution? We suggest that the answer could be found in changes in primary productivity during the Holocene at Caleta de Los Loros. Recently, Boretto et al. (2014), Bayer et al. (2016), and Morán et al. (2018) proposed that shell size differences between fossil and modern assemblages of bivalve mollusks in Northern Patagonia are due to an increase in paleo-productivity and upwelling processes. In this respect, Teusch et al. (2002) also associated upwelling intensity with morphological variation between Pleistocene and Recent turritellid gastropods from Chile. These authors found that shells from the Pleistocene were on average $14 \mathrm{~mm}$ longer than modern shells from the same area, indicating that larger shell size is associated with more intense upwelling, and the increase in the amount of shell material secreted may be explained by increased availability of food associated with stronger upwelling.

Interestingly, Morán et al. (2018) also detected at Caleta de Los Loros that Holocene shells of Ameghinomya antiqua a common bivalve predated by $T$. geversianus in the San Jorge Gulf (Gordillo \& Archuby, 2014)- were rounder and larger than modern ones. The opposite trend was observed between $T$. geversianus and Tawera gayi (another common bivalve currently predated by $T$. geversianus) at the Beagle Channel, where both species increase their body size towards the present (Malvé et al., 2018b). In any case, the covariation between predator and prey sizes is highly informative and worth pursuing, especially when opposite trends were observed involving the same predator but different prey, along the northern and southern end of its geographic distribution in Argentinean Patagonia. Altogether, the results of this study could be explained either in the context of a predator-prey relationship, and as a response to the environmental changes registered in the San Matías Gulf during the late Quaternary. These changes include variations in sea surface temperatures, salinity, substrate, and also water circulation changes, which would have modified nutrient availability (Bayer et al., 2016).

At this point, we have the comparison between shell size variation between modern and Holocene shells at two sites (Beagle Channel and Caleta de Los Loros) with a completely different geological history (Rabassa et al., 2000; Ponce et al., 2011). Both sites are wave-protected areas and behave as outliers, taking into account the latitudinal gradient considered (Malvé et al., 2018b).

In this respect, Caleta de Los Loros evolved from an open coast subjected to wave action to a more restricted system, leaving a deep, narrow open sector (Del Río \& Colado, 1999). Late Holocene assemblages were more exposed to wave action and the influence of tides. Nowadays, on exposed shores, strong wave action limits the abundance of crabs, hence gastropod shells become thinner and have longer apertures that allow the presence of a bigger foot to better attach to the substrate (Trussell \& Etter, 2001). In wave-exposed environments, it is important to remain attached to the substratum, and disturbed snails have to emerge quickly from their shell in order to re-attach (Johannesson, 2016; Leighton et al., 2016). On the contrary, on wave protected shores, crabs are more abundant and predation intensity is higher. So the fact that Holocene shells were thinner is in agreement with a higher energy habitat and with current theory on patterns of selection on gastropod shell morphology, although the taphonomic wear effect cannot be ruled out. It is already well known that shell shape in gastropods tends to be different on wave-exposed and wavesheltered shores (Johannesson, 2016). The heavy surf on wave-exposed shores is thought to select for small size, whereas the high risk of shell-breaking predation on wavesheltered shores is thought to select for increased shell size and thickness (Boulding et al., 1999; Pascoal et al., 2012).

In the near future, it would be extremely useful to begin a complete exploration of the latitudinal profile along the southwestern Atlantic to better elucidate shell size and shape evolution during the Late Quaternary in Patagonia.

Caleta de Los Loros as an outlier site. At first sight, Trophon geversianus shells from this peculiar place located in the Argentinean Province bear a closer resemblance to shells found in sites further south (e.g., Magellan Province), a fact that was confirmed by a cluster analysis. Two sites from the Magellan Province (Makenke and Punta Loyola) are located in urban estuaries and were grouped with localities from the Argentinean Province. The smaller sizes of both sites may be explained by the physicochemical properties of brackish water from these environments that could influence shell traits.

Interestingly, outlier sites come from the southern and 
northern extremes of the geographical distribution for this species on the Argentinean Patagonian coast. These three outliers (Caleta de Los Loros in northern Patagonia, and the Beagle Channel and Strait of Magellan in southern Patagonia) are sites characterized by protected shores, with calm waters, which are not directly exposed to the open sea. In northern Patagonia, upwelling events are predominant and the thermohaline front nearby provides very high concentrations of phytoplankton. In southern Patagonia, waters come from the Antarctic circumpolar current, which also has high primary productivity. Caleta de Los Loros, being a wave protected area, and an exceptional site situated in the northern sector of the mouth inside the San Matías Gulf, exhibits unusually large, thick shells for its geographic location. This situation could therefore be explained by the oceanographic features of the San Matías Gulf.

From an oceanographic point of view, Piola \& Scasso (1988) pointed out the presence of a zonal front (Front of the San Matías Gulf) during a large part of the year situated near $41^{\circ} 50^{\prime} \mathrm{S}$. These authors determined that the temperature difference between both regions reaches $3^{\circ} \mathrm{C}$, although it becomes negligible in the winter. A mass of colder, nutrient-rich water coming from the continental shelf can also be clearly noted. This water mass comes from the south and goes round the Valdés Peninsula until it reaches the mouth of San José Gulf, interacting with local waters and those of the southern sector of the San Matías Gulf (Gagliardini \& Rivas, 2004). Furthermore, Pisoni et al. (2014) found that sea surface temperature (SST) data reveals a narrow coastal band $(\sim 10 \mathrm{~km})$ of relatively cold water extending $\sim 100 \mathrm{~km}$ along the west coast of the San Matías Gulf. The SST in this band was $1.5^{\circ} \mathrm{C}$ lower than further offshore, suggesting that coastal upwelling is a dominant process controlling high-frequency temperature fluctuations near-shore.

Taking into account this oceanographic background, and considering that the upwelling of cooler, nutrient-rich waters towards the surface can trigger peaks in phytoplankton blooms, thus raising primary productivity, it is expected that grazer and filter-feeder populations (the main prey of Trophon geversianus) would thrive in the upwelling areas. Consequently, bivalves (Ameghinomya antiqua,
Brachidontes rodriguezii and Mytilus edulis) are larger at Caleta de Los Loros than in nearby sites (Morán et al., 2018, and the authors' personal observations). Larger sizes of $T$. geversianus in this area may be explained by the availability of larger prey via maximizing energy efficiency. Hence, attaining a larger size provides $T$. geversianus the opportunity to attack larger prey, thus increasing the amount of food obtained in a single, long, and energetically expensive event of drilling (Gordillo \& Archuby, 2012).

Finally, oceanic fronts can generate barriers preventing larvae or adults from crossing. These fronts represent major barriers to gene flow and have a strong influence on the population's genetic structure of some marine species (Galarza et al., 2009). Although a phylogenetic analysis of COI gene fragments in $T$. geversianus from Nuevo Gulf showed no consistent differences among individuals sampled in both intertidal and subtidal habitats (Márquez et al., 2015), so far, no genetic studies have been carried out on a regional scale.

\section{CONCLUDING REMARKS}

Trophon geversianus is a direct developer species (lacking free larvae), whose extreme shell variability generates highly different local morphs. This is the case of Caleta de Los Loros in which shells are unusually large, thick, and heavy according to its geographic location. Caleta de Los Loros and the Beagle Channel are both wave-protected shores that experienced a completely different geological history during the late Holocene; however these sites share, at present, high chlorophyll- $a$ and calcite concentrations, and have lower $\mathrm{pH}$ values than the rest of the Atlantic coast (Malvé et al., 2018a). As a result, these sites showed the larger sizes of $T$. geversianus along the whole study area.

Finally, Trophon geversianus exhibits opposite trends of shell size variation between modern and late Holocene sites across its northern and southern geographic distribution. These trends could be explained on the basis of predatorprey interactions along with strong environmental and oceanographic conditions related to upwelling events.

\section{ACKNOWLEDGMENTS}

We would like to thank E. Morsán, E. Lapa, and N. Dieu for their kind help and hospitality during fieldwork. A special mention is given to M. Adami who collaborated during sampling. MEM wants to acknowledge to Instituto de Desarrollo Costero (IDC-UNPSJB) for the 
use of facilities during processing sampling. We further acknowledge the editor D. G. Lazo and both reviewers, D. A. Pérez, and S. Nielsen, whose comments and suggestions improved the manuscript. Funding was provided by CONICET (PIP-114-20110100238) with the permission (Res. 1216) of the Province of Río Negro through the Secretaría de Ambiente y Desarrollo Sustentable (SAyDS). This study is also a contribution to the CONICET Project Cambios climáticos y variaciones ambientales en Caleta de Los Loros (Golfo San Matías) durante el Cuaternario tardio (PIP-112-20170100080).

\section{REFERENCES}

Aguirre, M. L., \& Farinati, E. A. (1999). Taphonomic processes affecting late Quaternary molluscs along the coastal area of Buenos Aires Province (Argentina, Southwestern Atlantic). Palaeogeography, Palaeoclimatology, Palaeoecology, 149(1-4), 283-304.

Archuby, F. M., Adami, M., Martinelli, J. C., Gordillo, S., Boretto, G. M., \& Malvé, M. E. (2015). Regional-scale compositional and size fidelity of rocky intertidal communities from the Patagonian Atlantic coast. Palaios, 30(8), 627-643.

Bayer, M. S., Morsán, E., Gordillo, S., \& Morán, G. (2016). Form changes in Amiantis purpurata (Bivalvia, Veneridae) shells over the past 100,000 years in North Patagonia (Argentina). Journal of the Marine Biological Association of the United Kingdom, 96(6), 1243-1250.

Blanchette, C. A., Miner, C. M., Raimondi, P. T., Lohse, D., Heady, K. E., \& Broitman, B. R. (2008). Biogeographical patterns of rocky intertidal communities along the Pacific coast of North America. Journal of Biogeography, 35(9), 1593-1607.

Boretto, G. M., Baranzelli, M. C., Gordillo, S., Consoloni, I., Zanchetta, G., \& Morán, G. (2014). Shell morphometric variations in a Patagonian Argentina clam (Ameghinomya antiqua) from the Mid-Pleistocene (MIS 7) to the present. Quaternary International, 352, 48-58.

Borthagaray, A. I., \& Carranza, A. (2007). Mussels as ecosystem engineers: their contribution to species richness in a rocky littoral community. Acta Oecologica, 31(3), 243-250.

Boulding, E. G., Holst, M., \& Pilon, V. (1999). Changes in selection on gastropod shell size and thickness with wave-exposure on northeastern pacific shores. Journal of Experimental Marine Biology and Ecology, 232(2), 217-239.

Caley, K., Grahame, J., \& Mill, P. J. (1995). A geographically-based study of shell shape in small rough periwinkles. Hydrobiologia, 309(1-3), 181-193.

Carriker, M. R. (1981). Shell penetration and feeding by naticacean and muricacean predatory gastropods: A synthesis. Malacologia, $20(2), 403-422$

Cazenave, K. R., \& Zanatta, D. T. (2016). Environmental drivers of shell shape in a freshwater gastropod from small and large lakes. Freshwater Science, 35(3), 948-957.

Chiu, Y. W., Chen, H. C., Lee, S. C., \& Chen, C. A. (2002). Morphometric analysis of shell and operculum variations in the viviparid snail, Cipangopaludina chinensis (Mollusca: Gastropoda), in Taiwan. Zoological Studies, 41(3), 321-331.

Cumplido, M., Averbuj, A., \& Bigatti, G. (2010). Reproductive seasonality and oviposition induction in Trophon geversianus (Gastropoda: Muricidae) from Golfo Nuevo, Argentina. Journal of Shellfish Research, 29(2), 423-428.

Del Río, J. L., \& Colado, U.R. (1999). Ambientes sedimentarios actuales de la Caleta de Los Loros, provincia de Río Negro, República Argentina. Thalassas, 15(1), 35-44.

Denny, M. W. (2006). Ocean waves, nearshore ecology, and natural selection. Aquatic Ecology, 40(4), 439-461.

Fenberg, P. B., \& Rivadeneira, M. M. (2011). Range limits and geographic patterns of abundance of the rocky intertidal owl limpet, Lottia gigantea. Journal of Biogeography, 38(12), 2286-2298.

Gagliardini, D. A., \& Rivas, A. L. (2004). Environmental characteristics of Golfo San Matías obtained from LANDSAT-TM and ETM+ data. Gayana, 68(2), 186-193.

Galarza, J. A., Carreras-Carbonell, J., Macpherson, E., Pascual, M., Roques, S., Turner, G. F., \& Rico, C. (2009). The influence of oceanographic fronts and early-life-history traits on connectivity among littoral fish species. Proceedings of the National Academy of Sciences, 106(5), 1473-1478.

Gentry, D. K., Sosdian, S., Grossman, E. L., Rosenthal, Y., Hicks, D., \& Lear, C. H. (2008). Stable isotope and Sr/Ca profiles from the marine gastropod Conus ermineus: testing a multiproxy approach for inferring paleotemperature and paleosalinity. Palaios, 23(4), 195-209.

Gordillo, S., \& Archuby, F. (2012). Predation by drilling gastropods and asteroids upon mussels in rocky shallow shores of southernmost South America: paleontological implications. Acta Palaeontologica Polonica, 57(3), 633-647.

Gordillo, S., \& Archuby, F. (2014). Live-live and live-dead interactions in marine death assemblages: the case of the Patagonian clam Venus antiqua. Acta Palaeontologica Polonica, 59(2), 429-443.

Gordillo, S., Brey, T., Beyer, K., \& Lomovasky, B. J. (2015). Climatic and environmental changes during the middle to late Holocene in southern South America: A sclerochronological approach using the bivalve Retrotapes exalbidus (Dillwyn) from the Beagle Channel. Quaternary International, 377(7), 83-90.

Griffin, M., \& Pastorino, G. (2005). The genus Trophon Monfort, 1810 (Gastropoda: Muricidae) in the Tertiary of Patagonia. Journal of Paleontology, 79(2), 296-311.

Harley, C. D., Denny, M. W., Mach, K. J., \& Miller, L. P. (2009). Thermal stress and morphological adaptations in limpets. Functional Ecology, 23(2), 292-301.

Huston, M. A. (1999). Local processes and regional patterns: appropriate scales for understanding variation in the diversity of plants and animals. Oikos, 86(3), 393-401.

Johannesson, K. (2016). What can be learnt from a snail? Evolutionary Applications, 9(1), 153-165.

Kelaher, B. P., Castilla, J. C., Prado, L., York, P., Schwindt, E., \& Bortolus, A. (2007). Spatial variation in molluscan assemblages from coralline turfs of Argentinean Patagonia. Journal of Molluscan Studies, 73(2), 139-146.

Kidwell, S. M. (2002). Time-averaged molluscan death assemblages: palimpsests of richness, snapshots of abundance. Geology, 30(9), 803-806

Kidwell, S. M. (2013). Time-averaging and fidelity of modern death assemblages: building a taphonomic foundation for conservation palaeobiology. Palaeontology, 56(3), 487-522.

Leighton, L. R., Chojnacki, N. C., Stafford, E. S., Tyler, C. L., \& Schneider, C. L. (2016). Categorization of shell fragments provides a proxy for environmental energy and predation intensity. Journal of the Geological Society, 173(5), 711-715.

Lleonart, J., Salat, J., \& Torres, G. J. (2000). Removing allometric effects of body size in morphological analysis. Journal of Theoretical Biology, 205(1), 85-93.

Madec, L., \& Bellido, A. (2007). Spatial variation of shell morphometrics in the subantarctic land snail Notodiscus hookeri from Crozet and Kerguelen Islands. Polar Biology, 30(12), 1571-1578.

Malvé, M. E., Gordillo, S., \& Rivadeneira, M. M. (2018a). Connecting $\mathrm{pH}$ with body size in the marine gastropod Trophon geversianus 
in a latitudinal gradient along the south-western Atlantic coast. Journal of the Marine Biological Association of the United Kingdom, 98(3), 449-456.

Malvé, M. E., Rivadeneira, M. M., \& Gordillo, S. (2018b). Biogeographic shell shape variation in Trophon geversianus (Gastropoda: Muricidae) along the southwestern Atlantic Coast. Palaios, 33(11), 498-507.

Márquez, F., Nieto-Vilela, R. A., Lozada, M., \& Bigatti, G. (2015). Morphological and behavioral differences in the gastropod Trophon geversianus associated to distinct environmental conditions, as revealed by a multidisciplinary approach. Journal of Sea Research 95, 239-247.

Morán, G. A., Martínez, J. J., Boretto, G. M., Gordillo, S., \& Boidi, F. J. (2018). Shell morphometric variation of Ameghinomya antiqua (Mollusca, Bivalvia) during the late quaternary reflects environmental changes in North Patagonia, Argentina. Quaternary International 490, 43-49.

Nekola, J. C. (2010). Acidophilic terrestrial gastropod communities of North America. Journal of Molluscan Studies, 76(2), 144-156.

Ostachuk, A. (2016). On novelty, heterochrony and developmental constraints in a complex morphological theory of recapitulation: the genus Trophon as a case study. Evolutionary Biology, 43(3), 392-406.

Pascoal, S., Carvalho, G., Creer, S., Mendo, S., \& Hughes, R. (2012). Plastic and heritable variation in shell thickness of the intertidal gastropod Nucella lapillus associated with risks of crab predation and wave action, and sexual maturation. PloS one, 7(12), e52134.

Pastorino, G. (2005). A revision of the genus Trophon Montfort, 1810 (Gastropoda: Muricidae) from southern South America. The Nautilus, 119(2), 55-82.

Penchaszadeh, P. E. (1976). Reproducción de gasterópodos prosobranquios del Atlántico suroccidental: el género Trophon. Physis, 35(90), 69-76.

Piola, A. R., \& Scasso, L. M. (1988). Circulación en el Golfo San Matías. Geoacta, 15(1), 33-51.

Pisoni, J. P., Rivas, A. L., \& Piola, A. R. (2014). Satellite remote sensing reveals coastal upwelling events in the Golfo San MatíasNorthern Patagonia. Remote Sensing of Environment, 152, 270-278.

Pizá, J., \& Cazzaniga, N. J. (2003). Redescription, shell variability and geographic distribution of Plagiodontes dentatus (Wood, 1828) (Gastropoda: Orthalicidae: Odontostominae) from Uruguay and Argentina. Zootaxa, 154(1), 1-23.

Ponce, J. F., Rabassa, J., Coronato, A., \& Borromei, A. M. (2011). Palaeogeographical evolution of the Atlantic coast of Pampa and Patagonia from the last glacial maximum to the Middle Holocene. Biological Journal of the Linnean Society, 103(2), 363379.

Prado, L., \& Castilla, J. C. (2006). The bioengineer Perumytilus purpuratus (Mollusca: Bivalvia) in central Chile: biodiversity, habitat structural complexity and environmental heterogeneity. Journal of the Marine Biological Association of the United Kingdom, 86(2), 417-421.

Rabassa, J., Coronato, A., Bujalesky, G., Salemme, M., Roig, C., Meglioli, A., \& Quattrocchio, M. (2000). Quaternary of Tierra del Fuego, southernmost South America: an updated review. Quaternary International 68, 217-240.

Ramajo, L., Baltanás, Á., Torres, R., Manríquez, P. H., RodriguezNavarro, A., \& Lagos, N. A. (2013). Geographical variation in shell morphology of juvenile snails (Concholepas concholepas) along the physical-chemical gradient of the Chilean coast. Journal of the Marine Biological Association of the United Kingdom, 93(8),
2167-2176

Resetarits, W. J. (2005). Habitat selection behaviour links local and regional scales in aquatic systems. Ecology Letters, 8(5), 480486.

Rivas, A. L. (1990). Heat balance and annual variation of mean temperature in the North-Patagonian gulfs. Oceanologica Acta, 13(3), 265-272.

Sander, L., Pejrup, M., Murray, A. S., Perillo, G. M. E., Raniolo, L. A., \& Fruergaard, M. (2018). Chronology and late-Holocene evolution of Caleta de Los Loros, NE Patagonia, Argentina. Holocene, 28(1), 1276-1287.

Sueiro, M. C., Bortolus, A., \& Schwindt, E. (2010). Habitat complexity and community composition: relationships between different ecosystem engineers and the associated macroinvertebrate assemblages. Helgoland Marine Research, 65(4), 467-477.

Teusch, K. P., Jones, D. S., \& Allmon, W. D. (2002). Morphological variation in turritellid gastropods from the Pleistocene to modern of Chile: association with upwelling intensity. Palaios, 17(4), 366-377.

Thorpe, R. S. (1975). Quantitative handling of characters useful in snake systematics with particular reference to intraspecific variation in the ringed snake Natrix natrix (L.). Biological Journal of the Linnean Society, 7, 27-43.

Trussell, G. C. (2000). Predator-induced plasticity and morphological trade-offs in latitudinally separated populations of Littorina obtusata. Evolutionary Ecology Research, 2(6), 803-822.

Trussell, G. C., \& Etter, R. J. (2001). Integrating genetic and environmental forces that shape the evolution of geographic variation in a marine snail. Genetica, 112(1), 321-337.

Trussell, G. C., Johnson, A. S., Rudolph, S. G., \& Gilfillan, E. S. (1993). Resistance to dislodgement: habitat and size-specific differences in morphology and tenacity in an intertidal snail. Marine Ecology Progress Series, 100(1-2), 135-144.

Trussell, G. C., \& Smith, L. D. (2000). Induced defenses in response to an invading crab predator: an explanation of historical and geographic phenotypic change. Proceedings of the National Academy of Sciences, 97(5), 2123-2127.

Vermeij, G. J., \& Covich, A. P. (1978). Coevolution of freshwater gastropods and their predators. The American Naturalist, 112(987), 833-843.

Yorio, P., Caille, G., Schwindt, E., Tagliorette, A., Esteves, J. L., Crespo, E., Arias, A., \& Harris, G. (2015). Conservación de la Diversidad Biológica en la Zona Costera de la Patagonia Argentina. In H. E. Zaixso \& A. L. Boraso (Eds.). La Zona Costera Patagónica Argentina. Volumen III: Pesca y Conservación (pp. 159-217). Editorial Universitaria de la Patagonia.

Zaixso, H. E. (1973). Observaciones sobre el desove y embriología de Trophon geversianus (Pallas) 1974 (Gastropoda, Muricidae). Contribución Científica 101, 156-162.

Zuschin, M., Stachowitsch, M., \& Stanton, R. J. Jr. (2003). Patterns and processes of shell fragmentation in modern and ancient marine environments. Earth-Science Reviews, 63(1-2), 33-82.

doi: 10.5710/AMGH.26.12.2019.3294

Submitted: September $7^{\text {th }}, 2019$

Accepted: December 26 ${ }^{\text {th }}, 2019$

Published online: December $31^{\text {th }}, 2019$ 